\title{
The Carbon Sinks and Mitigation Potential of Deodar (Cedrus deodara) Forest Ecosystem at Different Altitude in Kumrat Valley, Pakistan
}

\author{
Adnan Ahmad1,2, Muhammad Amir'1, Abdul Mannan'3, Sajjad Saeed1', Sher Shah', \\ Sami Ullah², Rahman Uddin ${ }^{2}$, Qijing Liu' ${ }^{1}$ \\ ${ }^{1}$ Department of Forest Sciences, Beijing Forestry University, Beijing, China \\ ${ }^{2}$ Shaheed Benazir Bhutto University, Sheringal, Dir Upper, Pakistan \\ ${ }^{3}$ Beijing Key Laboratory of Precision Forestry, Beijing Forestry University, Beijing, China \\ Email: liuqijing@bjfu.edu.cn, adnanfr@sbbu.edu.pk
}

How to cite this paper: Ahmad, A., Amir, M., Mannan, A., Saeed, S., Shah, S., Ullah, S., Uddin, R., \& Liu, Q. (2018). The Carbon Sinks and Mitigation Potential of Deodar (Cedrus deodara) Forest Ecosystem at Different Altitude in Kumrat Valley, Pakistan. Open Journal of Forestry, 8, 553-566. https://doi.org/10.4236/ojf.2018.84034

Received: July 20, 2018

Accepted: October 20, 2018

Published: October 23, 2018

Copyright $\odot 2018$ by authors and Scientific Research Publishing Inc. This work is licensed under the Creative Commons Attribution International License (CC BY 4.0).

http://creativecommons.org/licenses/by/4.0/

(c) (i) Open Access

\begin{abstract}
Forest carbon monitoring and reporting are critical for informing global climate change assessment. The regional estimates of forest carbon attached greater attention, to assess the role of forest in carbon mitigation. Here using field inventory, we examined the carbon sink and mitigation potential of monospecific Deodar forest in the Kumrat valley, of Hindu Kush Himalaya, Region of Pakistan, at a different elevation. The elevation of monospecific Deodar forest ranges from 2300 to $2700 \mathrm{~m}$ (a.s.l). We divided the forest into three elevation classes (that is $2300-2400 \mathrm{~m}$ (EI) $2400-2500 \mathrm{~m}$ (EII) and $2500-2700 \mathrm{~m}$ (EIII) a.s.l respectively). In each elevation class, we laid out 09 sample plots $\left(33^{*} 33 \mathrm{~m}^{2}\right)$ for measuring carbon values in living tree biomass (LT), soil (SC), litter, dead wood, cone (LDWC) and understory vegetation (USV). Our results showed that the carbon density at EI was $432.37 \pm 277.96$ $\mathrm{Mg} \cdot \mathrm{C}^{-1}$, while the carbon density at EII and EIII was $668.35 \pm 323.94$ and $1016.79 \pm 542.99 \mathrm{Mg} \cdot \mathrm{C}^{-1}$ respectively. Our finding revealed that the carbon mitigation potential of the forest increases with increasing elevation. Among the different elevation classes, EIII stored significantly higher carbon due to the dominance of mature, old age, larger trees, and the minimum anthropogenic disturbance, whereas EI stored statistically lower carbon because of maximum anthropogenic disturbance, which resulted in the removal of mature and over-mature trees. Furthermore, our correlation analysis between tree height and carbon stock and basal area and LT carbon, underlines that the basal area is the stronger predictor of LT carbon estimation than height. Overall our results highlight that deodar forest stored $716.94 \pm 462.06$ $\mathrm{Mg} \cdot \mathrm{C} \cdot \mathrm{ha}^{-1}$. However, the rehabilitation, preservation and sustainable man-
\end{abstract}


agement of disturb forest located at a lower elevation could considerably improve carbon mitigation potential.

\section{Keywords}

Deodar Forest, Elevation, Carbon Sinks, Mitigation Potential

\section{Introduction}

The increased emission of greenhouse gases (GHGs) since the industrial revolution significantly influenced the global environment. The growing concern of environmental changes because of climate change, the problem of carbon balance, the major GHG, is important and the removal of carbon and their storage in different terrestrial ecosystems for cutting down the increased level of carbon dioxide are required (Ardo \& Olsson, 2004). Forests are the major component of the carbon cycle and the global distribution of carbon in forests plays an important role in the carbon cycle (Zhang et al., 2013). Forests are extremely important in balancing of the carbon cycle by absorbing $2.9 \pm 0.8 \mathrm{PgC}$ each year (Le Quere et al., 2009; Calfapietra et al., 2015). Forests cover over 4 billion ha area of Earth Planet and the recent estimate of store carbon in world forest is $861 \pm 66 \mathrm{PgC}$ (Pan et al., 2011; Wani et al., 2014, 2015). However, other estimated carbon indicates that store carbon is in the range of 450 - $650 \mathrm{Pg}$ in biomass and 1500 - $2400 \mathrm{Pg}$ in soil and dead organic matter (Batjes, 1996; Prentice et al., 2001; IPCC, 2013).

Forestland has the ability to store and sink more carbon; forestland can hold 20 to 50 times more carbon (Houghton \& Hackler, 1995). The woody and long living nature of the forest make them more attractive tools for the stabilization and reduction of GHGs (Sharma \& Rai, 2007; Sharma et al., 2011). Forest carbon measurement and their management are critical for informing climate change (Kramer et al., 2015). The measurement of forest biomass carbon is required to understand the dynamics of carbon in forest and for making the decision to manage forest resources for climate change (Esser, 1984; Johnson \& Kern, 2002; Malhi et al., 2004). In the recent climate, change scenario and their mitigation concern at national and international level, carbon management through forest attached greater value (FAO, 2010). To address the challenge of global climate change the IPCC and UNFCC are working at the regional and international level. The Kyoto Protocol (1997) of the UNFCC is working to coupe the issue of climate change (Wani et al., 2012). The KP recognized that different terrestrial ecosystems forests, grassland, and wetland can potentially store and sequester carbon from the atmosphere and can therefore slow down the increased concentration of carbon dioxide (Ardo \& Olsson, 2004). The KP ranked the forestland as an important carbon sink, and included the sustainable management of forest in the second commitment period (2013-2020). The Durban Climate Change Conference also set rules for the emission reduction related to forestry and agroforestry activities (Calfapietra et al., 2015). The UNFCC and The KP give 
direction and guidelines for the measurement of carbon in the forest. To comply with the UNFCC and KP member countries periodically measure carbon in their forest ecosystems.

Pakistan is the member of the KP and UNFCC. The country has diverse ecology, forest types (Champion et al., 1963). The northern areas (NA) of Pakistan comprise of Hindu Kush, Karakorum, and Himalaya Ranges are the home of the forest. The estimates of forest carbon, a data gap in the northern part of Pakis$\tan$, are required in the present scenario of carbon management. The area is mostly dominated by the coniferous forest. Deodar (Cedrus deodara) the national tree of Pakistan is a long-living woody tree reaches up to the age of 500 to 700 years distributed at a range of $2000 \mathrm{~m}$ to $3000 \mathrm{~m}$ (Moinuddin et al., 2009; Khan et al., 2013). The tree is one of the most important dominant species of the region showing dynamics in stand structure and growing stock attributes, Moinuddin et al. $(2010,2011)$. Although the ecology regarding the species composition, stand structure and population dynamics has been worked out but, the carbon storage and mitigation services of the deodar community have been not studied yet. Taking the consideration in mind here, we conducted the present study to investigate the carbon mitigation potential of the tree. The research aimed to figure out the growing stocks attributes and biomass carbon of deodar forest at a different elevation. In this research, we developed regression models and guidelines for study the relation of stem density and diameter, stand basal area and stand volume. We also studied the relation of stand basal area and height with biomass carbon. We show that the stand basal area is a strong predictor of biomass carbon than stand height. It is expected that the present work would not only provide information regarding the current status and carbon dynamics but will also be helpful in the managing of forest for carbon and future carbon dynamics trend of deodar community in the region.

\section{Materials and Methods}

\subsection{Study Area}

The study area lies in Hindu Kush range, rich in forest resources. The area is dominated by the coniferous forest. The major coniferous species of the area are Cedrus deodara (Deodar), Pinus wallichiana (Kail), Abies pindrow (Fir), Picea smithiana (Spruce) and Taxus bacata. Among the broad-leaved, the common species include Juglans regia, Quercus incana, Aesculus indica, Poplus caspica, Parrotia jacquemontians, and Alnus Nitida. Deodar is found in the area as a single dominant species or form association with Kail, Fir, and spruce. The geographic location of the area is $35^{\circ} 31^{\prime} .46^{\prime} \mathrm{N}$ to $35^{\circ} 32^{\prime} .91^{\prime} \mathrm{N}$ and $71^{\circ} 06^{\prime} .18^{\prime \prime} 4 \mathrm{E}$ to $72^{\circ} 14.98$ ' $\mathrm{E}$. The elevation of the area ranges from $2100 \mathrm{~m}$ to $6000 \mathrm{~m}$. The deodar dominant community located at an elevation of 2300 to $2700 \mathrm{~m}$. The average rainfall is in the range of $800-1200 \mathrm{~mm}$. Temperature ranges from $0.10^{\circ} \mathrm{C}$ to $25^{\circ} \mathrm{C}$. Diorites, norities, schist are the major types of rocks. The soil $\mathrm{pH}$ is 5.83 to 6.22. The mean soil bulk density is $1.03 \mathrm{gm} \cdot \mathrm{cm}^{-1}$. The soil organic matter ranges from $3.12 \%$ to $4.77 \%$. 


\subsection{Research Design and Field Measurement}

We used stratified random sampling. The stratification was based on elevation. We divided the area of deodar community into three elevation classes ( $\mathrm{EI}=2300$ $-2400 \mathrm{~m}, \mathrm{EII}=2400-2500 \mathrm{~m}$, and EIII $=2500-2700 \mathrm{~m}$ ). In each class, we take ten sample plots randomly in 2014-15. The size of each sample plot was 0.1 ha. Overall 30 sample plots were taken. The elevation and geographic location of each plot were measured by using GPS. In each plot stem, density $\left(\mathrm{ha}^{-1}\right)$ was measured. We used a caliper and Abneys level for tree height $(\mathrm{m})$ and diameter (cm) measurement. Trees less than $6 \mathrm{~cm}$ diameter were not considered for enumeration. Local volume table also used for data computation. For understorey vegetation, litter, dead wood, and cones biomass measurement sample plots of 2 $\mathrm{m}^{2}$ were laid in each plot of 0.1 ha. For soil carbon in each elevation class, we collected the soil samples at the depth of, 0 to $15 \mathrm{~cm}$ and 15 to $30 \mathrm{~cm}$.

\subsection{Biomass Carbon Estimation}

We calculated the stem volume $\left(\mathrm{m}^{3} \cdot \mathrm{ha}^{-1}\right)$ from DBH and Tree height using (Philip, 1994). Stem biomass (t.ha $\left.{ }^{-1}\right)$ was measured from stem volume $\left(\mathrm{m}^{3} \cdot \mathrm{ha}^{-1}\right)$ and wood density $\left(\mathrm{kg}^{-1} \cdot \mathrm{m}^{3}\right)$ and then converted into total tree biomass $\left(\mathrm{t} \cdot \mathrm{ha}^{-1}\right)$ by using BEF (Haripriya, 2000; Fang et al., 2002; IPCC, 2003; Teobaldelli et al., 2009). The biomass of understory vegetation (UnSV) was measured by collecting the vegetation destructively from each subplot. The fresh weight $(\mathrm{kg})$ was calculated and samples of one $1 \mathrm{Kg}$ were brought to the laboratory and were dry for 48 hours at $72^{\circ} \mathrm{C}$ and their dry weight was calculated for biomass measurement. The deadwood litter and cone were also collected in each subplot for and their dry weight was measured from biomass calculation. For assessing the carbon content in each biomass component, we converted the biomass into carbon using a carbon-measuring fraction (0.5) following Equation (1) (IPCC, 2003; Sharma et al., 2010; Ahmad \& Nizami, 2015; Adnan et al., 2015; Ahmad et al., 2018; Manan et al., 2018)

$$
\operatorname{Carbon}\left(\mathrm{t} \cdot \mathrm{ha}^{-1}\right)=\operatorname{Biomass}\left(\mathrm{t} \cdot \mathrm{ha}^{-1}\right) * \operatorname{Carbon} \%(0.5)
$$

For soil carbon (SC) measurement soil samples were collected using soil auger and core with a known volume of $104 \mathrm{~cm}^{3}$ (height $=5.12 \mathrm{~cm}$ and diameter $=5.1$ $\mathrm{cm})$. The collected samples were analyzed by using Walkley and Black (1934) method. The percent organic matter was measured and form organic matter percentage we measured carbon content (\%). For the measurement of soil carbon in $\mathrm{t} \cdot \mathrm{ha}^{-1}$ we calculated the soil bulk density $\left(\mathrm{gm} \cdot \mathrm{cm}^{-3}\right)$ and using Equation (2), carbon in tha ${ }^{-1}$ was calculated (Pearson et al., 2008; Nizami, 2012; Ahmad et al., 2018).

$$
\text { Soil carbon }\left(\mathrm{t} \cdot \mathrm{ha}^{-1}\right)=\operatorname{SOC}(\%) * \operatorname{Soil~} \mathrm{BD}\left(\mathrm{gm} \cdot \mathrm{cm}^{-3}\right) * \operatorname{Soil~depth}(\mathrm{cm})
$$

\subsection{Statistical Analysis}

Std deviation (SD), and Std Error were worked out. Regression models were de- 
veloped to study the relationship between tree diameter $(\mathrm{cm})$ and stem density $\mathrm{ha}^{-1}$ using Sigma Plot V 12.5. Similarly, the relationship between stand basal area $\left(\mathrm{m}^{2} \cdot \mathrm{ha}^{-1}\right)$ and stem volume $\left(\mathrm{m}^{3} \cdot \mathrm{ha}^{-1}\right)$ and stand basal area $\left(\mathrm{m}^{2} \cdot \mathrm{ha}^{-1}\right)$ and total tree biomass ( $\mathrm{t} \cdot \mathrm{ha}^{-1}$ ) was worked out (Sigma Plot V 12.5). The regression model for carbon stock $\left(\mathrm{t} \cdot \mathrm{ha}^{-1}\right)$ estimation based on mean height $\left(\mathrm{ha}^{-1}\right)$ and mean basal area $\left(\mathrm{ha}^{-1}\right)$ were also developed using Sigma Plot V 12.5.

\section{Results}

\subsection{Growing Stock Characteristics}

Stem density varied from $203 \pm 107$ to $271 \pm 48$ trees.ha ${ }^{-1}$ with a mean value of $237 \pm 48$ trees $\cdot \mathrm{ha}^{-1}$. Details of tree distribution in respective diameter classes are given in Table 1. It can be seen from the table that in EI and EII about $66 \%$ to $70 \%$ trees are found in lower and middle diameter classes while in EIII about $40 \%$ trees are found in same diameter classes and the rest of trees are distributed in the upper diameter classes. Overall in deodar community about $40 \%-50 \%$ of trees occurred in the diameter classes from 66 to $178 \mathrm{~cm}$. The present study outlines that the tree distribution pattern is uneven at a different elevation (Table 1). The uneven distribution of trees can be linked with different factors like forest management operations, grazing problem and local people excess to the forest and forest classification into different working circles. The forest of the study area is managed under the selection system; the forest department carries logging operation under the selection system. The forest located at lower elevation received more logging and wood removal (only snags and fallen trees are removed) operations as compared to a higher elevation. Similarly, the local people have certain rights in the forest like grazing and fuelwood and timber collection, so due to easy excess, the forests located at lower elevation are the first choices. Forest located on higher elevation was designated as a protection forest for the watershed, and therefore received minimum logging and wood removal operation that resulted in the occurrences of more mature and over-mature trees (Table 1). The ban on green felling since 1992 also resulted in a comparatively more number of the trees in upper diameter classes. In comparison the mean value of stem density in the present study falls within the ranges reported by (Moinuddin et al., 2011) from deodar community at different altitudes from Pakistan. However, the current value of stem density gives lower estimates from the reported value of tree density from the Himalaya region of Kashmir and western India by (Wani et al., 2015). The reason of more density may be the presences of small diameter trees and the absences of large diameter trees. The author reported trees of $10-110 \mathrm{~cm}$ diameter while in the present study we recorded trees up to diameter $178 \mathrm{~cm}$.

The presence of larger diameter trees resulted in a higher value of the basal area (Table 2). The basal area in the ELIII $(2500-2700 \mathrm{~m})$ was the highest among all elevation classes. Similarly, the stem volume was also maximum at altitude $2500-7000 \mathrm{~m}$. The basal area $\left(\mathrm{m}^{2} \cdot \mathrm{ha}^{-1}\right)$ and tree height $(\mathrm{m})$ depend on tree diameter; forest having trees of larger diameter produces more value of basal 
Table 1. Percent stem density distribution pattern in respective diameter classes $(\mathrm{cm})$.

\begin{tabular}{cccc}
\hline Diameter class $(\mathrm{cm})$ & $2300-2400(\mathrm{~m})$ & $2400-2500(\mathrm{~m})$ & $2500-2700(\mathrm{~m})$ \\
\hline $10-34$ & 40.17 & 34.44 & 17.07 \\
$36-64$ & 28.38 & 21.48 & 23.69 \\
$66-94$ & 17.9 & 18.89 & 17.77 \\
$96-124$ & 8.30 & 12.22 & 23.34 \\
$126-178$ & 5.24 & 12.96 & 18.12 \\
Total & 100 & 100 & 100 \\
\hline
\end{tabular}

Table 2. Growing stock and biomass in respective elevation.

\begin{tabular}{ccccc}
\hline S.No & $2300-2400$ & $2400-2500$ & $2500-2700$ & Mean \\
\hline $\begin{array}{c}\text { Density } \cdot \mathrm{ha}^{-1} \\
\text { Basal Area } \mathrm{m}^{2} \cdot \mathrm{ha}^{-1}\end{array}$ & $203 \pm 101$ & $238 \pm 71$ & $271 \pm 48$ & $237 \pm 78$ \\
Height $(\mathrm{m})$ & $27.09 \pm 5.91$ & $27.97 \pm 4.59$ & $33.16 \pm 6.37$ & $29.40 \pm 5.62$ \\
Volume $\mathrm{m}^{3} \cdot \mathrm{ha}^{-1}$ & $999.4 \pm 852.6$ & $1703.4 \pm 888.8$ & $2707.05 \pm 1554.5$ & $1835.65 \pm 504.07$ \\
Stem Biomass t.ha & & $126.6 \pm 58.4$ & $198.8 \pm 104.2$ & $137.43 \pm 35.93$ \\
Total tree biomass t.ha & $692.2 \pm 556.1$ & $1177.9 \pm 639.1$ & $1904.2 \pm 1093.8$ & $1281.46 \pm 360.58$ \\
UnSV biomass t.ha ${ }^{-1}$ & $3.37 \pm 1.2$ & $2.11 \pm 0.21$ & $2.42 \pm 0.70$ & $2.63 \pm 0.37$ \\
DWCL, biomass t $\cdot \mathrm{ha}^{-1}$ & $15.60 \pm 10.8$ & $14.50 \pm 8.01$ & $4.65 \pm 2.32$ & $11.58 \pm 3.48$ \\
\hline
\end{tabular}

area and height (Nizami, 2012; Adnan et al., 2015). Furthermore, the volume $\left(\mathrm{m}^{3} \cdot \mathrm{ha}^{-1}\right)$ of a stand is the function of stand basal area $\left(\mathrm{m}^{2} \cdot \mathrm{ha}^{-1}\right)$, higher the value of basal area higher will be the volume (Philips, 1994; Sajjad et al., 2016). The relationship of stand basal area and stand volume has been presented in Figure 1. The value of $\mathrm{R}^{2}(0.99)$ in Table 3 , depicted a highly positive correlation of basal area with stand volume. The presences of smaller diameter trees in lower elevation resulted in a minimum value of height basal area and volume as compared to forest community located at middle and higher altitude. Overall our results of tree height and basal area are consistent with the results of (Champion et al., 1963; Sheikh, 1993; Moinuddin et al., 2011).

\subsection{Biomass}

Along the elevation, the highest value of USVB was recorded at EIII fallowed by EII. The UVB was maximum in the ELI due to presences of more woody shrubs. The DWCLB of ELI and ELII was recorded high as compare to ELIII due to more woody debris and cone on the forest floor. Growing stock volume based estimation of forest biomass is a reliable source and a major predictor of the above-ground biomass (Häme et al., 1992; Shavidenko et al., 2007; Somogyi et al., 2008). The biomass measurement in a forest determines the ability of forest for sink and source of carbon (Brown et al., 1999). The forest biomass measurement is also needed for predicting the change of carbon in different carbon pool, 


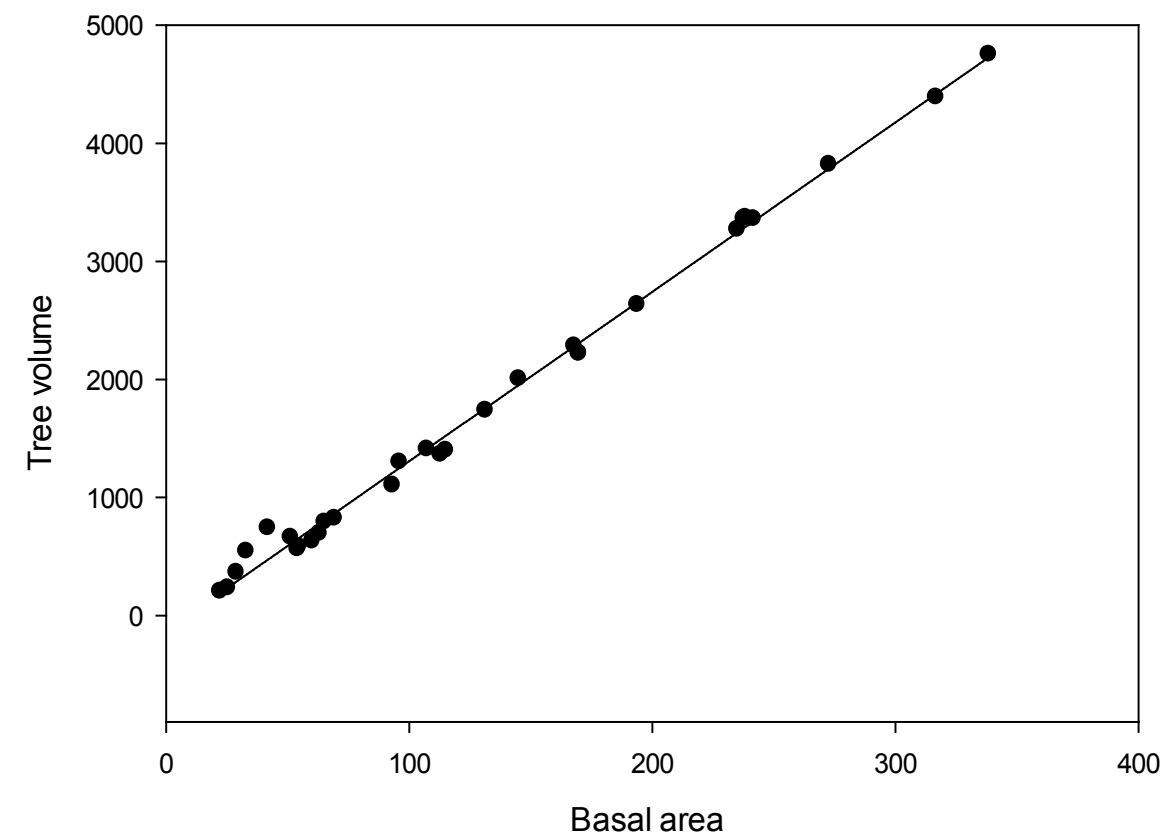

Figure 1. Relationship b/w tree Basal area $\left(\mathrm{m}^{2} \cdot \mathrm{ha}^{-1}\right)$ and Tree volume $\mathrm{m}^{3} \cdot \mathrm{ha}^{-1}\left(\mathrm{R}^{2}=0.99\right.$, $\mathrm{P} \leq 0.0001)$.

Table 3. Regressions equations for growing stock parameters, biomass and carbon stock.

\begin{tabular}{|c|c|c|c|c|c|}
\hline Relation & Equation Type & $\mathrm{y} 0$ & A & $\mathrm{P}$ & $\mathrm{R}^{2}$ \\
\hline $\begin{array}{l}\text { Basal area } \mathrm{m}^{2} \cdot \mathrm{ha}^{-1} \\
\text { and volume } \mathrm{m}^{3} \cdot \mathrm{ha}^{-1}\end{array}$ & P. Linear $\left(f=y 0+a^{\star} x\right)$ & -126.8 & 14.34 & $<0.0001$ & 0.99 \\
\hline $\begin{array}{l}\text { Basal area } \mathrm{m}^{2} \cdot \mathrm{ha}^{-1} \\
\text { and biomass } \mathrm{t} \cdot \mathrm{ha}^{-1}\end{array}$ & P. Linear $\left(\left(f=y 0+a^{\star} x\right)\right.$ & -101.4 & 10.09 & $<0.0001$ & 0.99 \\
\hline $\begin{array}{l}\text { Mean Height }(\mathrm{m}) \\
\text { and C. Stock th.ha }\end{array}$ & P. Linear $\left(f=y 0+a^{\star} x\right)$ & -722.06 & 45.42 & $<0.0001$ & 0.60 \\
\hline $\begin{array}{l}\text { Basal area } \mathrm{m}^{2} \cdot \mathrm{ha}^{-1} \text { and } \mathrm{C} . \\
\text { Stock } \mathrm{t} \cdot \mathrm{ha}^{-1}\end{array}$ & P. Linear $\left(f=y 0+a^{\star} x\right)$ & -50.86 & 5.046 & $<0.0001$ & 0.99 \\
\hline
\end{tabular}

(Esser, 1984). The biomass in a forest can be in measured two ways. To convert measured growing stock volume, to biomass by using basic wood density and $\mathrm{BEF}$ and to estimates biomass directly from growing stock volume and BECF without using wood density (IPCC, 2003; IPCC, 2006; Tolnnay, 2011). In the present study, we convert the growing stock volume to biomass using BEF. The USV biomass was higher at the elevation 2500-2700 which are similar to the study of (Sharma et al., 2011) who reported the highest biomass at the same altitude as India. The value of UnSV and DWCL biomass (Table 2) was more in ELI. At ELI more woody shrubs like Indigofera wallichiana, Berberislycium, Berberisfrakraian, and Rosa webbiana were found with other forbs and grasses like Caltha alba, Rumuxdentatus, Artemisia vulgaris Bergenia ciliate Cthe ynodondacttylon, Agropyrondentatum, A. Canaliculatum and Poe spp. The occurrences of more woody shrubs and dense UnSV resulted in more value of UnSV and DWCL biomass. 


\subsection{Biomass Carbon}

The value of carbon density was assessed in USVB, UnSVB, and DWCL Biomass and in Soil. Details of total carbon are given in Table 4. It can be seen from the table that among different elevation, there is significant variation in carbon density. EIII significantly store more carbon comparable to EII and EI. The UpSV in ELIII hold more carbon than EI and EII. In the EIII, the occurrences of more number of trees in higher diameter classes as compare to EII and ELIII resulted in more value of basal area and carbon. The biomass carbon of the UnSV was higher in the ELI because of dense understory vegetation. The occurrence of more woody shrubs in the lower elevation also resulted in more UnSV biomass carbon. Similarly, in ELI, DWCL carbon and soil carbon was also higher as compare EII and EIII .On the forest floor at a lower elevation; there was more dead wood in the form of woody debris, small branches and twigs, which may be the reason of more dead wood, and litter carbon. Similarly, in the lower elevation, some area have been also affected by dieback that developed a slightly more wood debris and cone on the forest floor which resulted in more DWLC biomass carbon. The recorded SOC was also greater in the lower elevation as compared to higher elevation due to the presence of more organic matter in the top soil as a result of more woody debris on the forest floor. The forest located at higher elevation also has slightly more soil erosion because of more sloppy nature that also resulted to low soil carbon. In comparison, we reported higher biomass carbon from the reported value of the (Sharma et al., 2011). The biomass carbon $\left(\mathrm{t} \cdot \mathrm{h}^{-1}\right)$ in a forest is the function of basal area $\left(\mathrm{m}^{2} \cdot \mathrm{ha}^{-1}\right)$ with an increase in the basal area of the tree the value of biomass carbon increases (Nizami, 2012; Adnan et al., 2014). In the current study, we developed the relationship between basal area and biomass carbon (Figure 2, Table 3). The value of $\mathrm{R}^{2}(0.99)$ support the arguments of the functional relation of basal area and biomass carbon. In the present study, we also developed the relationship between the mean height $(\mathrm{m})$ and total carbon $\left(\mathrm{t} \cdot \mathrm{ha}^{-1}\right)$. Figure 3 describes the functional relation between tree mean height and biomass carbon the value $\mathrm{R}^{2}=0.60$ (Table 3 ) give a slight week functional relation of mean tree height $\left(\mathrm{ha}^{-1}\right)$ with biomass carbon as compare to the relation of the basal area with total tree biomass carbon. It can be concluded from our present results that the basal area of the stand is a strong predictor of biomass carbon than mean tree height.

Soil carbon is an integral part of the forest ecosystem and major carbon pool. The results of our study of soil carbon give lower value from the reported value of various authors (Gupta \& Sharma, 2011) that reported soil carbon in the range of $120.35 \pm 25 \mathrm{t} \cdot \mathrm{ha}^{-1}$ to $145 \mathrm{t} \cdot \mathrm{ha}^{-1}$ under deodar forest community from the Himalaya ranges of India. We attributed the lower estimates to various factors like grazing, fuelwood collection and soil erosion problems. The forest of the area is protected forest with different rights like grazing, timber, and fuelwood collection for domestic purposes. The trampling effect of the animal can cause soil compaction that would result in the low amount of carbon in soil. The 
Table 4. Carbon density in each pool.

\begin{tabular}{cccccc}
\hline Carbon Pool & $2300-2400 \mathrm{~m}$ & $2400-2500 \mathrm{~m}$ & $2500-2700 \mathrm{~m}$ & Mean & $\%$ \\
\hline UpSV Carbon tha $^{-1}$ & $345.9 \pm 277.90$ & $589.03 \pm 319.50$ & $952.3 \pm 547.04$ & $640.6 \pm 467.60$ & 87.75 \\
UnSV Carbon t.ha $^{-1}$ & $1.6 \pm 0.60$ & $1.05 \pm 0.10$ & $1.2 \pm 0.30$ & $2.63 \pm 019$ & 0.37 \\
DWCL Carbon t.ha & $7.8 \pm 5.40$ & $7.25 \pm 40$ & $2.35 \pm 1.10$ & $11.58 \pm 1.47$ & 1.65 \\
SO Carbon thha & $76.8 \pm 5.50$ & $71.01 \pm 5.03$ & $60.9 \pm 8.30$ & $69.57 \pm 6.27$ & 10.21 \\
Total Carbon tha $^{-1}$ & $432.3 \pm 289.50$ & $668.3 \pm 323.90$ & $1016.7 \pm 542.90$ & $716.94 \pm 462.00$ & 100 \\
\hline
\end{tabular}

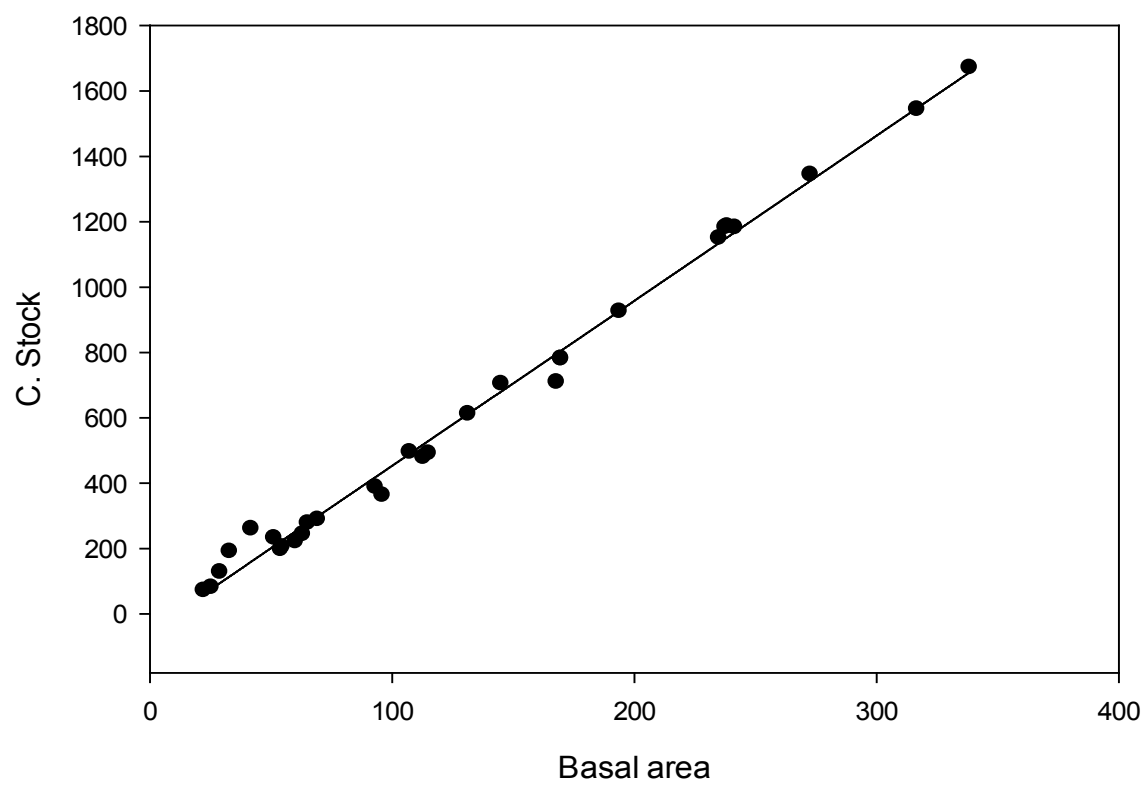

Figure 2. Relationship b/w tree basal area $\left(\mathrm{m}^{2} \cdot \mathrm{ha}^{-1}\right)$ and Carbon stock $\left(\mathrm{t} \cdot \mathrm{ha} \mathrm{a}^{-1}\right)\left(\mathrm{R}^{2}=0.99\right.$, $\mathrm{P} \leq 0.0001)$.

soil in a forest has organic and inorganic carbon, the organic carbon that is the important component of soil stored in the soil organic matter. The organic matter in a soil is the function of residence time (Luo et al., 2001). The residence time is variable in the forest carbon pools (Gaudinski et al., 2000). Litter and fine roots have short residence time while the dead wood has long residence time (Calfapietra et al., 2015). The residence time of the dead wood varies in a forest depending on climate conditions and forest types (Barbati et al., 2007). The forest management operation greatly affected the amount of dead wood in a forest due to the removal of a snag and coarse woody debris (Calfapietra et al., 2015). Similar situation exist in the studded forest the removal of the dead and dry wood (snags) by the forest department and local community resulted in low amount of dead wood and woody debris on the forest floor that resulted in low SOM content and soil organic carbon. One of the reasons of lower soil carbon is the location and topography of the deodar community, the deodar community, particularly in the higher elevation, occurred on sloppy terrines that causing more soil erosion that decreases SOM in topsoil. 


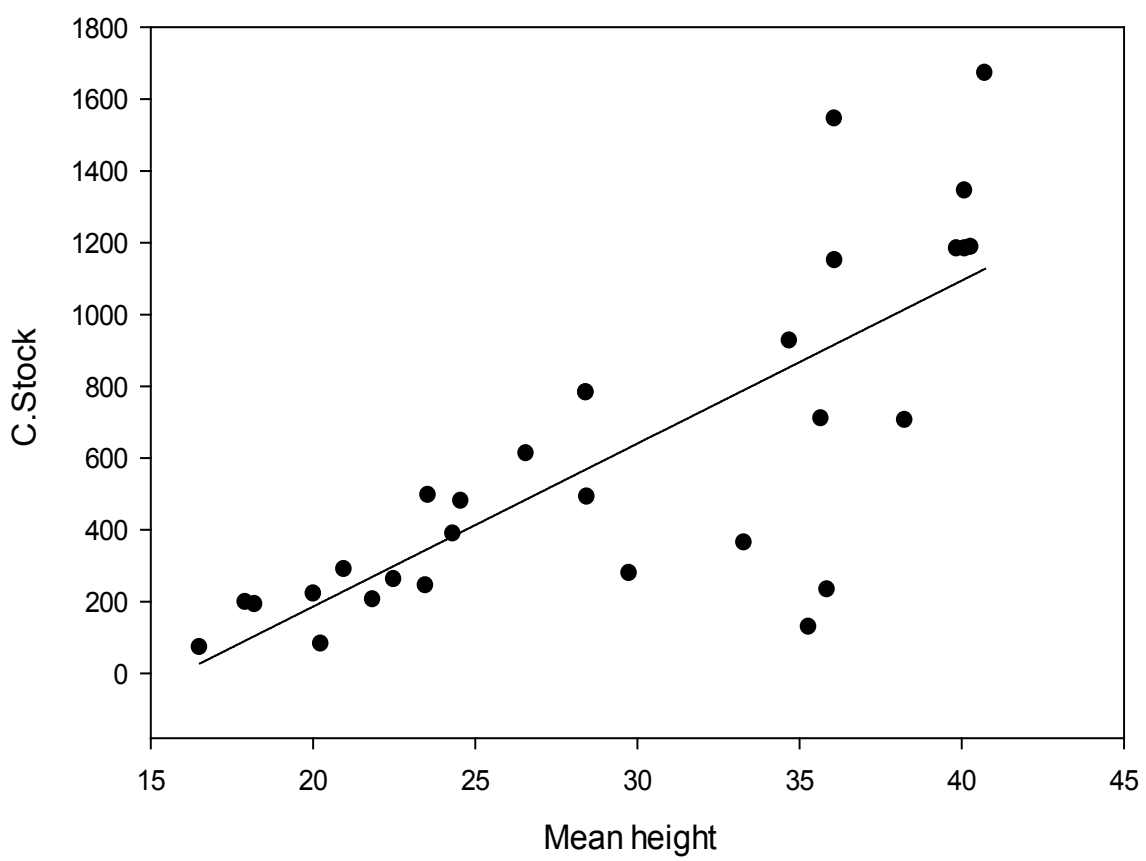

Figure 3. Relationship $\mathrm{b} / \mathrm{w}$ tree mean height $(\mathrm{m})$ and Carbon stock $\left(\mathrm{t} \cdot \mathrm{ha} \mathrm{a}^{-1}\right)\left(\mathrm{R}^{2}=0.60, \mathrm{P} \leq\right.$ $0.0001)$.

Mature forest with fully stocked and old age have a significant amount of carbon (Sharma et al., 2011). The natural old growth forest holds the potentially higher amount of carbon (Smithwick et al., 2002). The higher carbon stock of the mature and old forest are linked with higher tree layer biomass with long living nature and time-dependent carbon accumulation (Law et al., 2001; Pregitzer \& Euskrichen, 2004; Fredeen et al., 2005; Zhang et al., 2012). The deodar community of the study area consisting of old age tree up to 600 years (Khan et al., 2013) with larger diameter reaches up to $178 \mathrm{~cm}$. The presence of old age, mature and larger trees resulted in the higher amount of carbon (716.94 \pm 462$)$ as compare to other deodar forest located in the Himalaya ranges of India and Kashmir. However, the results of our study are consistent with the results of (Zhang et al., 2012) who reported $632 \mathrm{t} \cdot \mathrm{ha}^{-1}$ carbon from the mature fir forest. Our results also support the arguments that mature old forest can stored from 200 to 500 to 1900 t.ha ${ }^{-1}$ carbon (Geoff Craggs, 2016).

The control of deforestation and the promotion of planted forest have been suggested for global warming reduction (Bala et al., 2007). The mitigation of elevated carbon dioxide can be effectively reduced through plantation (Watson, 2000). However, the conservation of the natural and old age forest with a large amount of carbon is the effective way to reduce the amount of carbon in the atmosphere and to mitigate the climate change. Mature forest continuously accumulates a significant amount of carbon (Zhang et al., 2013). The finding of the present study confirmed that the deodar forest community consisting of old age trees acts as a potential carbon sink having the highest carbon mitigation ability across the Himalaya range of the Subcontinent. The results indicated that the 
deodar community had the stronger capacity to sequester and hold carbon in the present climate change context. The conservation of the forest based on responsive carbon management approaches will be the effective means to sequester and store atmospheric carbon in the recent climate change context.

\section{Conflicts of Interest}

The authors declare no conflicts of interest regarding the publication of this paper.

\section{References}

Adnan, A., Mirza, S. N., \& Nizami, S. M. (2014). Assessment of Biomass and Carbon Stocks in Coniferous Forest of Dir Kohistan, KPK. Pakistan Journal of Agricultural Sciences, 51, 345-350.

Adnan, A., Nizami, S. M., Marwat, K. B., \& Muhammad, J. (2015). Annual Accumulation of Carbon in Coniferous Forest of Dir Kohistan: An Inventory Based Estimate. Pakistan Journal of Botany, 47, 115-118.

Ahmad, A., \& Nizami, S. M. (2015). Carbon Stocks of Different Land Uses in the Kumrat Valley, Hindu Kush Region of Pakistan. Journal of Forest Research, 26, 57-64. https://doi.org/10.1007/s11676-014-0008-6

Ahmad, A., Liu, Q. J., Nizami, S. M., Mannan, A., \& Saeed, S. (2018). Carbon Emission from Deforestation, Forest Degradation and Wood Harvest in the Temperate Region of Hindukush Himalaya, Pakistan between 1994 and 2016. Land Use Policy, 1, 781-790. https://doi.org/10.1016/j.landusepol.2018.07.009

Ardö, J., \& Olsson, L. (2004). Soil Carbon Sequestration in Traditional Farming in Sudanese Dry Lands. Environmental Management, 33, 318-329. https://doi.org/10.1007/s00267-003-9141-2

Bala, G., Caldeira, K., Wickett, M., Phillips, T. J., Lobel, D. B., Delire, C., \& Mirin, A. (2007). Combined Climate and Carbon-Cycle Effects of Largescale Deforestation. Proceedings of the National Academy of Sciences USA, 104, 6550-6555. https://doi.org/10.1073/pnas.0608998104

Barbati, A., Corona, P., \& Marchetti, M. (2007). A Forest Typology for Monitoring Sustainable Forest Management: The Case of European Forest Types. Plant Biosystems, 1, 93-103. https://doi.org/10.1080/11263500601153842

Batjes, N. H. (1996). Total Carbon and Nitrogen in the Soils of the World. European Journal of Soil Science, 47, 151-163. https://doi.org/10.1111/j.1365-2389.1996.tb01386.x

Brown, S. L., Schrooder, P., \& Kern, J. S. (1999). Spatial Distribution of Biomass in Forests of the Eastern USA. Forest Ecology and Management, 123, 81-90. https://doi.org/10.1016/S0378-1127(99)00017-1

Calfapietra, C., Barbati, A., Perugini, L., Ferrari, B., Guidolotti, G., Quatrini, A., \& Corona, P. (2015). Carbon Stocks and Potential Carbon Sequestration of Different Forest Ecosystems under Climate Change and Various Management Regimes in Italy. Ecosystem Health and Sustainability, 1, 25. https://doi.org/10.1890/EHS15-0023

Champion, H. G., Seth, S. K., \& Khattak, G. M. (1963). Manual of Silviculture for Pakistan. Peshawar: Pakistan Forest Institute.

Esser, G. (1984). The Significance of Biospheric Carbon Pools and Fluxes for the Atmospheric $\mathrm{CO}_{2}$ : A Proposal Mode Structure. In: H. Leith, R. Fantechi, \& H. Schnitzler (Eds.), Interactions between Climate and Biosphere, Progress in Biometerology (pp. 
253-294). Lisse: Swets and Zeitlinger BV.

Fang, J. Y., Chen, A. P., Zhao, S. Q., \& Ci, L. J. (2002). Calculating Forest Biomass Changes in China-Response. Science, 296, 1359. https://doi.org/10.1126/science.296.5572.1359a

FAO (2010). Managing Forests for Climate Change. http://www.fao.org/docrep/013/i1960e/i1960e00.pdf

Fredeen, A. L., Bois, C. H., Janzen, D. T., \& Sanborn, P. T. (2005). Comparison of Coniferous Forest Carbon Stocks between Old-Growth and Young Second-Growth Forests on Two Soil Types in Central British Columbia, Canada. Canadian Journal of Forest Research, 35, 1411-1421.

Gaudinski, J. B., Trumbore, S. E., Davidson, E. A., \& Zheng, S. (2000). Soil Carbon Cycling in a Temperate Forest: Radio Carbon Based Estimates of Residence Times, Sequestration Rates and Partitioning of Fluxes. Biogeochemistry, 51, 33-69. https://doi.org/10.1023/A:1006301010014

Geoff Craggs, J. P. (2016). Strategic Analysis Paper the Role of Old-Growth Forests in Carbon Sequestration. Future Directions International. Independent Strategic Analysis of Australi's Global Interest.

Gupta, L. M. K., \& Sharma, S. D. (2011). Sequestrated Carbon: Organic Carbon Pool in the Soils under Different Forest Covers and Land Uses in Garhwal Himalayan Region of India. International Journal of Agriculture and Forestry, 1, 14-20.

Häme, T., Salli, A., \& Lahti, K. (1992). Estimation of Carbon Storage in Boreal Forests Using Remote Sensing Data. In M. Kanninen, \& P. Anttila (Eds.), Pilot Study. The Finnish Research Program on Climate Change, Progress Report (pp. 250-255). Helsinki: Academy of Finland.

Haripriya, G. S. (2000). Estimates of Biomass in Indian Forests. Biomass and Bioenergy, 19, 245-258.

Houghton, R. A., \& Hackler, J. L. (1995). Continental Scale Estimate of the Biotic Carbon Flux from Land Cover Change 1850-1990. ORNL/CDIAC-79, NDP-050. Oak Ridge, Tennessee: Carbon Dioxide Information Analysis Center, Oak Ridge National Laboratory, U.S. Department of Energy.

IPCC (2003). Good Practice Guidance for Land Use, Land Use Change and Forestry. Hayama: Institute for Global Environmental Strategies.

IPCC (2006). Guidelines for National Greenhouse Gas Inventories. In S. Eggleston, L. Buendia, K. Miwa, T. Ngara, \& K. Tanabe (Eds.), Volume 4, Agriculture, Forestry and Other Land Use (AFLOLU). Hayama: Institute for Global Environmental Strategies.

IPCC (2013). Climate Change 2013: The Physical Science Basis. Working Group I Contribution to the Fifth Assessment Report of the Intergovernmental Panel on Climate Change.

Johnson, M. G., \& Kern, J. S. (2002). Quantifying the Organic Carbon Held in Forested Soil of United State and Puerto Rico. In J. M. Kimble, L. S. Heath, R. A. Birdsey, \& R. Lal (Eds.), The Potential of US Forest Soil to Sequester Carbon and Mitigate the Greenhouse Effect. Boca Raton, FL: Lewis Publisher.

Khan, N., Ahmed, M., \& Shaukat, S. S. (2013). Climatic Signal in Tree-Rings Chronologies of Cedrus deodara Rom Chitral Hindukush Range of Pakistan. Geochronometer, 40, 195-207.

Kramer, R. C., Ramler, I., Sharp, R., Haddad, N. M., Gerber, J. S., West, P. C. et al. (2015). Degradation in Carbon Stocks near Tropical Forest Edges. Nature Communications. http://www.nature.com/naturecommunications 
Law, B. E., Thornton, P. E., Irvine, J. A., \& Vantuyl, P. M. (2001). Carbon Storage and Fluxes Forests as Global Carbon Sinks. Nature, 455, 213-215.

Le Quere, C., Raupach, R. M. R., Canadell, J. G., \& Marland, G. (2009). Trends in the Sources and Sinks of Carbon Dioxide. Nature Geoscience, 2, 831-836. https://doi.org/10.1038/ngeo689

Luo, Y., Wu, L., Andrews, J. A., White, L., Matamala, R., Schafer, V. R., \& Schlesinger, W. H. (2001). Elevated $\mathrm{CO}_{2}$ Differentiate Secosystem Carbon Processes: Deconvolution Analysis of Duke Forest FACE Data. Ecological Monographs, 71, 357-376.

Malhi, Y., Baker, T. R., Phillips, O. L., Almeida, S., Alvarez, E., Arroyo, L., Chave, J., Czimcziki, C. I., Fiore, A. D., Higuchi, N., Killeen, T. J., Laurance, S. G., Laurance, W. F., Lewis, S. L., Montoya, L. M. M., \& Lloyd, J. (2004). The Above Ground Coarse Wood Productivity of 104 Neotropical Forest Plots. Global Change Biology, 10, 563-591. https://doi.org/10.1111/j.1529-8817.2003.00778.x

Manan, A., Feng, Z., Ahmad, A., Liu, J., Saeed, A., \& Mukete, B. (2018). Carbon Dynamic Shifts with Land Use Change in Margallah Hills National Park, Islamabad (Pakistan) from 1990 to 2017. Applied Ecology and Environmental Research, 16, 3197-3214. https://doi.org/10.15666/aeer/1603_31973214

Moinuddin, A., Nazim, K., Siddiqui, M. F., Wahab, M., Khan, N., Khan, M. U., \& Hussain, S. S. (2010). Community Description of Deodar Forests from Himalayan Range of Pakistan. Pakistan Journal of Botany, 42, 3091-3102.

Moinuddin, A., Shaukat, S. S., \& Siddiqui, M. F. (2011). A Multivariate Analysis of the Vegetation of Cedrus deodara Forests in Hindu Kush and Himalayan Ranges of Pakistan: Evaluating the Structure and Dynamics. Turkish Journal of Botany, 35, 419-438.

Moinuddin, A., Wahab, M., Khan, N., Siddiqui, M. F., Khan, M. U., \& Hussain, S. T. (2009). Age and Growth Rates of Some Gymnosperms of Pakistan: A Dendrochronological Approach. Pakistan Journal of Botany, 41, 849-860.

Nizami, S. M. (2012). The Inventory of the Carbon Stocks in Sub Tropical Forest of Pakistan for Reporting under Kyoto Protocol. Journal of Forest Research, 23, 377-384.

Pan, Y., Birdsey, R. A., Fang, J., Houghton, R., Kauppi, P. E., Kurz, W. A., Phillips, O. L., Shvidenko, A., Lewis, S. L., \& Canadell, J. G. (2011). A Large and Persistent Carbon Sink in the World's Forests. Science, 333, 988-993. https://doi.org/10.1126/science.1201609

Pearson, T. R., Brown, S. L., \& Birdsey, R. A. (2008). Measurement Guidelines for The Sequestration of Forest Carbon. General Technical Report, USAD Forest Service.

Philip, M. S. (1994). Measuring Trees and Forests (2nd ed.). Wallingford, CT: CAB International.

Philip, M. S. (1994). Measuring Trees and Forests (2nd ed.). Wallingford: CAB International.

Pregitzer, K. S., \& Euskirchen, E. S. (2004). Carbon Cycling and Storage in World Forests: Biome Patterns Related to Forest Age. Global Change Biology, 10, 2052-2077.

Prentice, I. C. et al. (2001). The Carbon Cycle and Atmospheric Carbon Dioxide. In J. T. Houghton, Y. Ding, D. J. Griggs, M. Noquer, P. J. van der Linden, X. Dai, K. Maskell, \& C. A. Johnson (Eds.), Climate Change 2001: The Scientific Basis (pp. 183-237). Contribution of Working Group I to the Third Assessment Report of the Intergovernmental Panel on Climate Change, Cambridge and New York, NY: Cambridge University Press.

Sajjad, S., Adnan, A., \& Ashraf, I. (2016). The Bela Forest Ecosystem of District Jhelum, a Potential Carbon Sink. Pakistan Journal of Botany, 48, 121-129. 
Sharma, C. M., Gairola, S., Baduni, N. P., Ghildiyal, S., \& Sarvesh, K. S. (2011). Variation in Carbon Stocks on Different Slope Aspects in Seven Major Types of Temperate Region of Garhwal Himalaya. Indian Journal of Biosciences, 36, 701-708.

Sharma, P., \& Rai, S. C. (2007). Carbon Sequestration with Land-Use Cover Change in a Himalayan Watershed. Geoderma, 139, 371-378. https://doi.org/10.1016/j.geoderma.2007.02.016

Sheikh, M. I. (1993). Trees of Pakistan. Peshawar: Pakistan Forest Institute

Smithwick, E. A. H., Harmon, M. E., Remillard, S. M., Acker, S. A., \& Franklin, J. F. (2002). Potential Upper Bounds of Carbon Stores in Forests of the Pacific Northwest. Ecological Applications, 12, 1303-1317. https://doi.org/10.1890/1051-0761(2002)012[1303:PUBOCS]2.0.CO;2

Somogyi, Z., Teobaldelli, M., Federici, S., Matteucci, G., Pagliari, V., \& Grassi, G. (2008). Allometric Biomass and Carbon Factors Database. Journal of Biogeosciences and Forestry, 1, 107-113.

Teobaldelli, M., Somogyi, Z., Migliavacca, M., \& Usoltsev, V. A. (2009). Generalized Functions of Biomass Expansion Factors for Conifers and Broadleaved by Stand Age, Growing Stock and Site Index. Forest Ecology and Management, 257, 1004-1010.

Tolnnay, D. (2011). Total Carbon Stocks and Carbon Accumulation in Living Tree Biomass in Forest Ecosystem of Turkey. Turkish Journal of Agriculture and Forestry, 35, 256-279.

Tolnnay, D. (2011). Total Carbon Stocks and Carbon Accumulation in Living Tree Biomass in Forest Ecosystem of Turkey. Turkish Journal of Agriculture and Forestry, 35, 256-279.

Walkley, A., \& Black, J. A. (1934). An Examination of the Degtjaref Method for Determining Soil Organic Matter and Proposed Modification of the Chromic Titration Method. Soil Science, 37, 29-38. https://doi.org/10.1097/00010694-193401000-00003

Wani, A. A., Joshi, K. P., Singh, O., \& Pandey, R. (2012). Carbon Sequestration Potential of Indian Forestry Land. Nature and Science, 10, 78-85.

Wani, A. A., Joshi, P., Singh, O., \& Bhat, J. (2014). Estimating Soil Carbon Storage and Mitigation under Temperate Coniferous Forests in the Southern Region of Kashmir Himalayas. Mitigation and Adaptation Strategies for Global Change, 19, 1179-1194. https://doi.org/10.1007/s11027-013-9466-y

Wani, A. M., Joshi, P. K., \& Singh, O. (2015). Estimating Biomass and Carbon Mitigation of Temperate Coniferous Forests Using Spectral Modeling and Field Inventory Data. Ecological Informatics, 25, 63-70.

Watson, R. T. (2000). Land Use, Land-Use Change, and Forestry: A Special Report of the IPCC. Cambridge: Cambridge University Press.

Zhang, Y., Fengxue, G., Shirong, L., Yanchun, L., \& Chao, L. (2012). Variation of Carbon Stock with Forest Types Subalpine Region of South Western China. Forest Ecology and Management, 30, 88-95.

Zhang, Y., Gu, F., Liu, S., Liu, Y., \& Li, C. (2013). Variations of Carbon Stock with Forest Types in Subalpine Region of Southwestern China. Forest Ecology and Management, 300, 88-95. https://doi.org/10.1016/j.foreco.2012.06.010 